\title{
MEASUREMENT OF NITRATE LEACHING POTENTIAL OF A VERTISOL USING BROMIDE AS A TRACER UNDER RAINIFED CONDITIONS OF THE INDIAN SEMI-AIRID TROPICS
}

\author{
Ashok K. Patral and Thomas J. Rego
}

\begin{abstract}
High temperatures and evaporation in stmmer (April-June) and erratic rainfall in the wet season (July-September) are common features of the harsh environment of Indian semiarid tropics (SAT). The rainfall of this region often occurs in large storms punctuated by discrete dry spells. During excessive rainy periods there is a strong possibility that a large part of the resident soil-N, especially $\mathrm{NO}_{3}^{-}, \mathrm{NO}_{2}^{-}$etc., may move beyond the root zone with the excess water percolating down the soil profile. To understand the $\mathrm{N}$ losses through leaching in a deep Vertisol (depth $>150 \mathrm{~cm}$ ) of the Indian SAT, a field experiment was conducted during the "wet" season (June-September) of 1992 under rainfed conditions, using bromide $\left(\mathrm{Br}^{-}\right)$as a tracer for $\mathrm{NO}_{3}^{-}$. Bromide (as $\mathrm{NaBr}$ ) at $200 \mathrm{~kg} \mathrm{ha}^{-1}$ was applied onto the surface of a bare fallow soil, in microplots $\left(200 \times 200 \mathrm{~cm}^{2}\right)$, on Jume 15, and its verticnl movement to $100 \mathrm{~cm}$ was monitored weekly. Results showed that $\mathrm{Br}^{-}$distribution was influenced strongly by rainfall. After 1 week (June 15-22), with a rainfall of $64 \mathrm{~mm}, \mathrm{Br}^{-}$was found to a depth of $60 \mathrm{~cm}$, and whereas most $(40 \%)$ was in the top layer $(0-10 \mathrm{~cm})$, a total of $90 \%$ of applied $\mathrm{Br}^{-}$was recovered to a depth of $60 \mathrm{~cm}$. With large storms occurring in early July (e.g., $68 \mathrm{~mm}$ on July 2 ), $\mathrm{Br}^{-}$was moved further down the profile and accumulated largely in the 30 to $40-\mathrm{cm}$ layer. In early August, because of continuous heavy rainfall, almost all $\mathrm{Br}^{-}$had migrated beyond $50 \mathrm{~cm}$ depth. Approximately $40 \%$ was not found within the profile $(0-100 \mathrm{~cm})$ on September 11 . In dry spells during late August and early September, upward movement of 10 to $20 \%$ of Br$^{-}$was also noticed at 60 to $100 \mathrm{~cm}$ depth. Thus, the results demonstrate that early August may be a critical period for maximum $\mathrm{NO}_{3}^{-}$leaching in this soil and emphasize the need of advance strategies to reduce these effects in view of increasing need for $\mathrm{N}$ use efficiency and reduction of ground water contamination.
\end{abstract}

\begin{abstract}
TN India, 70\% of the cultivated area (136.18 million ha) is under rainfed agriculture. Productivity of this area is not stable, and in many regions it is precariously low because of poor soil fertility and resource constraints (e.g., irrigation, fertilizers, improved seeds etc.). This problem is widespread in the semiarid areas of the country where two dominant soil types, red soils (Alfisols) and black soils (Vertisols), cover the major portion of the farmed land. Indian Vertisols, in general, have
\end{abstract}

lalemational Crops Research linstiule lor the Semi.Arid Tropits (ICRISAT), Patancheru, Andhra Pradesh 502 324, India.

Current address: Indian Grassland and Fodder Research Instilule, Jhansi 284003 , Utiar Pradesh, India. Dt. Patra is corresponding author, Emalt? igfriox $X 400$.nicgw.nic.in

Recrived July 10, 1996; actepted June 13, 1997 less than $1 \%$ organic $\mathrm{C}$, and their total $\mathrm{N}$ content rarely exceeds $0.1 \%$ (Virmani et al. 1982). It has been demonstrated that crop response to fertilizer Nuse on cultivated Vertisols of the Indian SAT is good even under rainfed conditions (El-Swaify et al. 1985). However, fertilizer use is still not widely adopted because of the economic risk perceived to be associated with the variable soil moisture regimes under SAT conditions and its effects on processes affecting $\mathrm{N}$ availability in the soil. The rainfall in SAT is erratic; it occurs often in large storms, punctuated by discrete dry spells (Huda et al. 1988). During excessive rainy periods there is a strong possibility that a large part of the resident soil- $\mathrm{N}$, especially $\mathrm{NO}_{3}^{-}$, may move beyond the root zone, with the excess water percolating down the soil profile. Such losses of $\mathrm{N}$ from these 
soils cause reduced $\mathrm{N}$ economy as well as increased ground water load with $\mathrm{NO}_{3}^{-}$. The mignitude of $\mathrm{N}$ use efficiency (or losses) in semiarid regions of India is influenced strongly not only by climate but also by many soil factors (e.g., soil depth, native fertility, etc.). The loss mechanisms operating in Vertisols have been studied in several locations. For example, Craswell and Martin (1974) demonstrated that denitrification was important in Australian Vertisols after heavy rainfill events, provided adequate energy was available to drive the denitrification process. Other re-searchers have found that ammonia volatilization was a potential problem when urea was surface applied (Hargrove 1988; Patra et al. 1996). In other studies, the recovery of applied ${ }^{15} \mathrm{~N}$ in drainage water indicated the loss of $\mathrm{N}$ through leaching from Vertisols (Kissel et al. 1974). In the deep Vertisols of the Indian SAT, however, it his been presumed that leaching is confined to the onset of the rainy season when the water percolates through soils readily (Krantz and Kampen 1978) because of impermeability to water when saturated (Virgo 1981). Similar assumptions for Indian Vertisols have also been made by other workers (Hong et al. 1992; Katyal 1994). These assumptions, however, have yet to be supported by direct measurement of $\mathrm{NO}_{\mathfrak{z}}^{-}$losses in field conditions.

In the present study a field experiment was conducted to investigate the pattern of $\mathrm{Br}^{-}$ movement and to estimate the potential for $\mathrm{NO}_{3}^{-}$ leaching losses from a deep Vertisol under rainfed semiarid tropical conditions of this agro-climatic region.

In this study, bromide $\left(\mathrm{Br}^{-}\right)$was used as a tracer for $\mathrm{NO}_{3}^{-}$because of their similarity in charge and mobility in soil-water systems and low $\mathrm{Br}$ background concentration. For example, using soil columns, Smith and Davis (1974) observed that movement of $\mathrm{Br}^{-}$in subsoils is the sime as that of $\mathrm{NO}_{3}^{-}$. On irrigated plots, Hargrove and Bausch (1973) used the leaching rate of $\mathrm{Br}^{-}$as a standard of comparison for the leaching of three $N$ fertilizer sources. Onken et al. (1977) used large trrigated field plots and reported that $\mathrm{NO}_{3}^{-}$and $\mathrm{Br}$ move similarly in soil under field conditions. The use of $\mathrm{Br}^{-}$to assess the potential for $\mathrm{NO}_{3}^{-}$ movement has also been made by several other workers (see Bowman 1984; Levy and Chambers 1987; Silvertooth et al. 1992). Bromide has the additional advantages of neither degrading nor volatilizing and, thus, is not lost from the soil profile other than by deep leaching or plant uptake (Silvertooth et al. 1992; Li et al. 1995). The dis- advantage is that because $\mathrm{Br}$ is a biologically conserved tracer, a complete picture of the fate of fertilizer $N$ in soil-plant systems cannot be determined (Silvertooth et al. 1992).

\section{MATERIALS AND METHODS}

\section{Clintte}

The experiment was conducted during the wet season of 1992 at the ICRISAT Center, which is located about $26 \mathrm{~km}$ northwest of Hyderabad, India $\left(17^{\circ} \mathrm{N}, 78^{\circ} \mathrm{E}\right.$, altitude $\left.545 \mathrm{~m}\right)$. The climatic pattern of this region is characterized by high temperatures (mean $26^{\circ} \mathrm{C}$ ) and a stronglyseasonal and highly variable rainfill. The mean annual precipitation (1966-1995) at the ICRISAT center is $826 \mathrm{~mm}$, with more than $80 \%$ falling between early June and early October (Fig. 1) in the southwest monsoon. Typically, a substantial proportion of annual rainfall in this region comes in brief irregular and intense storms that create nutrient losses and erosion problems (El-Swaify etal. 1985; Huda et al. 1988). Onset of rain is also relatively unpredictable and highly variable in mature during this season. The co-efficient of variation of annual rainfall in SAT is 20-30\%. May is the hottest month in the region, when maximum and minimum temperatures (30-year average) remain about $39^{\circ}$ and $25^{\circ} \mathrm{C}$, respectively. During the wet season (July-September), these temperatures have been recorded at around $30^{\circ}$ and $20^{\circ} \mathrm{C}$, respectively. Another feature of the climate is the high annual potential evaporation rate (annual mean $1756 \mathrm{~mm}$ ) (Fig. 1), the highest rates occurring in the hot months prior to the rainy season; thus the maximum daily open pan evaporation occurs in May. In the rainy season, daily evaporation may be as low as $1 \mathrm{~mm}$, but it rises to 8 to $9 \mathrm{~mm}$ on clear days. A total of $28 \mathrm{~mm}$ of rain fell during May and $34 \mathrm{~mm}$ fell on June 10, 1992. These early showers aided tillage operation and preparation of the plots for the present experiment.

\section{Soil}

The soil was a deep fine smectitic, calcareous, hyperthermic Typic Pellustert (mean depth $>150$ $\mathrm{cm}$ ) (black soil). The clay content increases only slightly with depth. Before commencing the experiment, soil samples were collected at $10-\mathrm{cm}$ increments of to a depth of $100 \mathrm{~cm}$ to characterize the physical and chemical properties (Tiable 1). For soil analysis, $\mathrm{pH}$ was determined by a glass electrode, organic-C by dichromate oxidation (Walkley and Black 1934), and cation exchange capacity by $1 \mathrm{~N}$ sodium acetare solution ( $\mathrm{pH} 8.2$ ) 


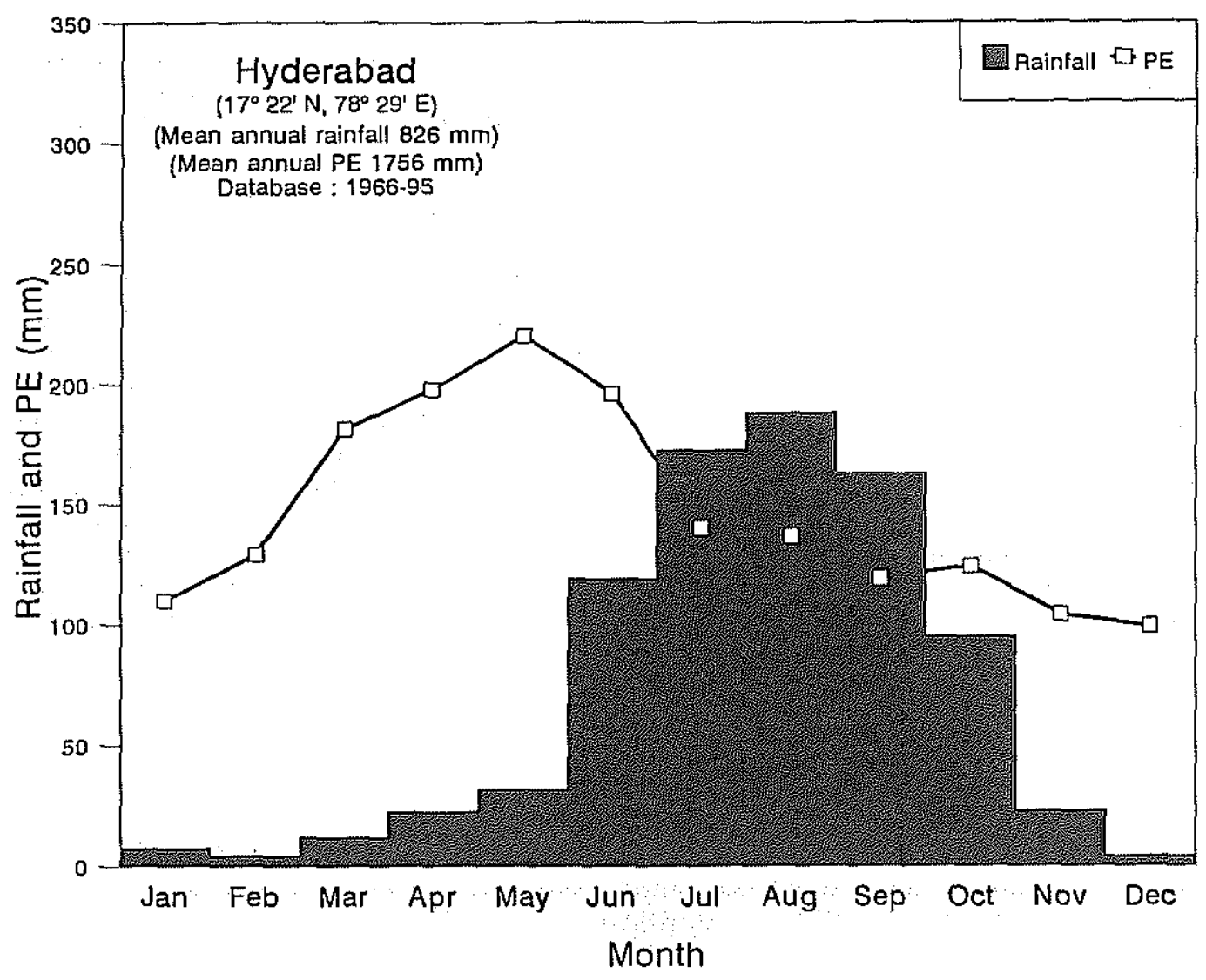

Fig. 1. Monthly rainfall and potential evaporation (PE) of Hyderabad, India.

as described by Jackson (1967). Anmonium and $\mathrm{NO}_{3}^{-}$contents were determined with $\mathrm{MgO}$ and Devardas alloy as described by Bremner (1965), and total $\mathrm{N}$ by Kjeldahl method (Bremner and Mulvaney 1982). The bulk density was measured using cylindrical metal core samplers as described by Blake (1965).

\section{Experimental}

This experiment was conducted in microplots constructed with iron barriers, $30 \mathrm{~cm}$ high and $200 \times 200 \mathrm{~cm}^{2}$ in area, embedded in the soil to a depth of $20 \mathrm{~cm}$ to prevent run-off losses. In addition, each microplot was protected by a border of aluminium sheet placed at a $50-\mathrm{cm}$ distance and inserted to the same depth $(20 \mathrm{~cm})$. There were three replications of the treatment. A control plot was not included in the experiment as the background concentration of $\mathrm{Br}^{-}$was negligible $\left(<1 \mathrm{nng} \mathrm{kg}^{-1}\right)$. The layout of the experimental plots is presented in Fig. 2.

On June 15, 1992, bromide (as $\mathrm{NaBr}$, AR grade) dissolved in $1000 \mathrm{~mL}$ distilled water was applied uniformly with a hand-held sprayer over the entire soil surface of each microplot at a rate of 200 $\mathrm{kg} \mathrm{ha-1}$. At this rate, $103 \mathrm{~g} \mathrm{NaBr}$ was required for each microplot. Before applying the $\mathrm{Br}$ - solution, several trials were given in the neighboring arei with same amount of $\mathrm{NaBr}$-free water to determine a method for uniform distribution of $\mathrm{Br}^{-m}$ on the experimental plots. Bromide was also applied at the same rate to the area between the iron barrier and the aluminium sheet to reduce the possible effects of lateral movement, from the treated microplot areas. One day after application, the $\mathrm{NaBr}$ was incorporated lightly into the soil to a depth of $5 \mathrm{~cm}$ with a small garden type hand cultivator (Bicki and Lei 1991). The plots were kept weed free, and no crop was grown. 
TABLE 1

Some properties of the soil (Vertisol) at different depths, in May 1992

\begin{tabular}{|c|c|c|c|c|c|c|c|c|c|c|}
\hline \multirow[b]{2}{*}{ Property } & \multicolumn{10}{|c|}{ Depth $(\mathrm{cm})$} \\
\hline & $0-10$ & $10-20$ & $20-30$ & $30-40$ & $+0-50$ & $50-60$ & $60-70$ & $70-80$ & $80-90$ & $90-100$ \\
\hline $\mathrm{pH}(1: 2$ soil to water $)$ & 8.35 & 8.35 & 8.35 & 8.40 & 8.40 & 8.43 & 8.50 & 8.55 & 8.50 & 8.70 \\
\hline $\mathrm{CEC}\left(\mathrm{cmol}(+) \mathrm{kg}^{-1}\right)$ & 38 & 38 & 45 & t4 & +8 & +7 & 46 & 41 & 49 & 50 \\
\hline Organie-C $(\%)$ & 0.51 & 0,50 & 0.48 & 0.44 & 0.46 & 0.42 & 0.41 & 0.38 & 0.39 & 0.39 \\
\hline $\begin{array}{l}\mathrm{NH}^{+}-\mathrm{N} \\
\left(\mathrm{mg} \mathrm{kg}^{-1}\right)\end{array}$ & 6.4 & 5.3 & 5.9 & +.3 & 3.3 & 4,2 & +.5 & 4.8 & +.5 & +.5 \\
\hline $\begin{array}{l}\mathrm{NO}_{3}^{-}-\mathrm{N} \\
\left(\mathrm{mg} \mathrm{kg}{ }^{\prime \prime I}\right)\end{array}$ & 1.5 & 20 & 2.0 & 1.0 & 2.1 & 2.2 & $<1,0$ & 1.8 & t.1 & 1.5 \\
\hline$B r^{-}\left(\mathrm{mg} \mathrm{kg}^{-1}\right)$ & $<1.0$ & $<1.0$ & $<1.0$ & $<1.0$ & $<1.0$ & $<1.0$ & $<1.0$ & $<1.0$ & $<1.0$ & $<1.0$ \\
\hline $\begin{array}{l}\text { Total-N } \\
\text { (mg kg } \mathrm{kg}^{-1} \text {. }\end{array}$ & 551 & 535 & 466 & 435 & 438 & +104 & 372 & 352 & 361 & $3+5$ \\
\hline $\mathrm{C} / \mathrm{N}$ & 9.2 & 9.3 & 10.3 & 10.1 & 10.5 & 10.4 & 11.0 & 10.8 & 10.8 & 11.3 \\
\hline $\begin{array}{l}\text { Bulk density } \\
\left(\mathrm{Mg} \mathrm{m}^{-3}\right)\end{array}$ & 1.18 & 1.22 & 1.25 & 1.37 & 1.43 & $1.4 t$ & 1.43 & $1 .+2$ & 1.41 & 1.41 \\
\hline
\end{tabular}

Soil samples were taken using core samplers $(6 \mathrm{~cm}$ diameter) in increments of 10 to $100 \mathrm{~cm}$ at various dates after $\mathrm{Br}^{-}$application, except on September 11 when sampling was made up to a depth of $150 \mathrm{~cm}$. Each sample hole was back-. filled with soil of the same depth from an adjacent area. Samples collected for each depth were transferred to labeled, air-tight, polyethylene bags and stored in a freezer until the time of chemical extraction. Before analysis, soil samples were made free of visible roots, debris, stones $(>2 \mathrm{~mm})$, etc. A portion of the wet soil was used for moisture content and another portion for $\mathrm{Br}^{-}$extraction. Moisture content was estimated gravimetrically and changed to volumetric using bulk density. Bromide in soil was measured by the method of Abdalla and Lear (1975), with some modifications to improve the accuracy ofB $r^{-}$recovery from the soil (Patra and Rego 1994). $\mathrm{Br}^{-}$was estimated by shaking $25-\mathrm{g}$ soil samples with $49 \mathrm{~mL}$ of distilled water and 1 $\mathrm{mL}$ of $5 \mathrm{MNaNO}_{3}$ as an ion strength adjuster for 30 min., followed by filtration. The filtrate was then used for $\mathrm{Br}^{-}$estimation using an ion-specific electrode (model PHM 85 precision $\mathrm{pH}$ meter, Radiometer, Copenhagen, Denmark). Occasionally the filtrate samples were stored in a refrigerator $\left(4^{\circ} \mathrm{C}\right)$ until concentration measurement. The $\mathrm{Br}$ - recovery (\%) for each $10-\mathrm{cm}$ incremental depth was determined using the following approach:
Soil sampling dates and daily rainfall distribution during the experimental period are presented in Fig. 3. Total precipitation $(597 \mathrm{~mm})$ from June to October 1992 was slightly higher than the 30-year average of $582 \mathrm{~mm}$ for the Hyderabad region (ICRISAT 1978). The daily weather data, e.g., rainfall and evaporation, used in this experiment were collected from the ICRISAT meteorological observatory.

\section{RESULTS AND DISCUSSION}

The vertical concentration profiles of $\mathrm{Br}^{-}$on different dates are shown in Fig. 4, and the total percent mass recoveries of applied $\mathrm{Br}^{-}$in the top $100 \mathrm{~cm}$ are given in Table 2 . The data indicate a strong influence of rainfall on the behavior of $\mathrm{Br}^{-}$(Fig. 4). For example, on June 22, i.e. 1 week after $\mathrm{Br}^{-}$application and after $60 \mathrm{~mm}$ of rainfall, $\mathrm{Br}^{-}$was distributed up to $50 \mathrm{~cm}$ depth. However, as much as $42 \%$ of $\mathrm{Br}^{-}$was retained in the surface layer $(0-10 \mathrm{~cm})$, and about $30 \%$ in the 10 to 20 cm samples. Below $20 \mathrm{~cm}$, the rest of the applied $\mathrm{Br}^{-}$decreased with depth.

On July 6 , atter the heavy rainfall on July $1(20$ $\mathrm{mm})$ and the largest $(68 \mathrm{~mm})$ of the year on July 2 (Fig. 3), the downward movement of $\mathrm{Br}^{-}$was enhanced greatly. In fact, only a small amount $(<10 \%)$ of $\mathrm{Br}^{-}$was present in the top 0 to $20 \mathrm{~cm}$, and an almost equal amount in the 20 to $30-\mathrm{cm}$ layer. The data indicate that most of the $\mathrm{Br}^{-}$was accumulated at the 30 to $70-\mathrm{cm}$ depth after these events. The distribution pattern of $\mathrm{Br}^{-}$in the profile on July 20 was 


\section{Vertisol

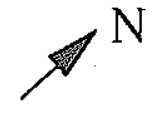

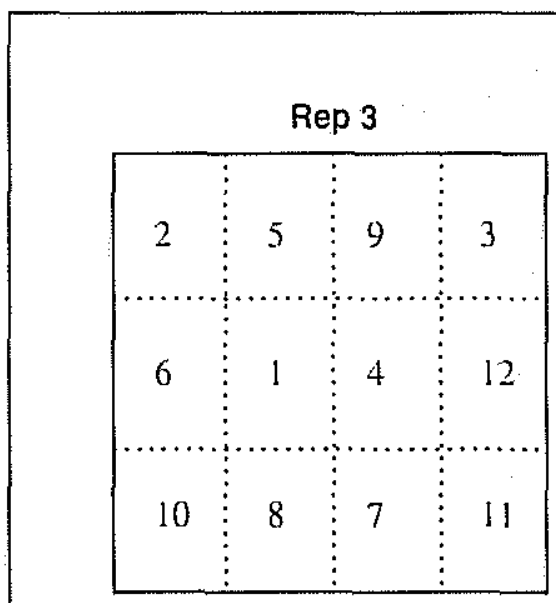

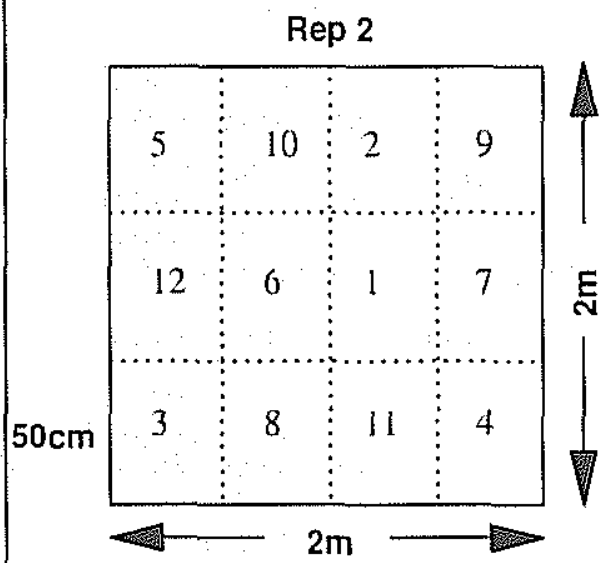

Rep 1

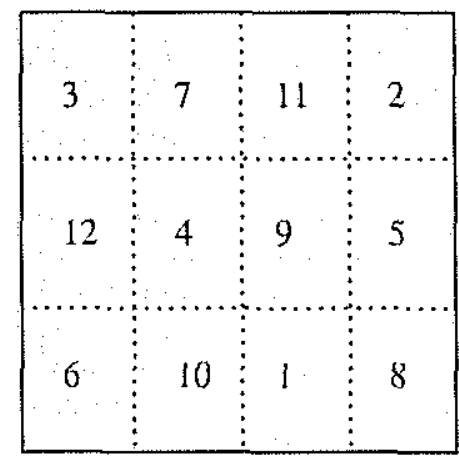

\section{Aluminium sheet}

Fig. 2. Field plot layout. Locations of soil sampling (1 to 12) are shown in each microplot. Rep indicates replication. somewhat similar to that of July 6 , but the amount of $\mathrm{Br}^{-}$in each layer was comparatively higher. This suggests that $\mathrm{Br}^{-}$had accumulated beyond $80 \mathrm{~cm}$ depch and some had moved upward during a dry period of 1 week before sampling on 20 July.

The observation made on August 17 (Table 2) was of grear significance in the context of $\mathrm{NO}_{3}^{-}$ leaching. Because of excessive rainfall $(2.18 \mathrm{~mm})$ during the first half of August, a large volume of water may have infiltrated at the soil surface resulting in transport of the $\mathrm{Br}^{-}$that had accumulated previously in the 20 to $60-\mathrm{cm}$ layer to a depth beyond $100 \mathrm{~cm}$. As a result, on August 17 only $36 \%$ of the applied $\mathrm{Br}^{-}$was recovered in the 0 to 100 -cm profile. In the subsequent sampling days intil September 11, with dry spells in late August and early. September, an increase $(10-20 \%)$ in $\mathrm{Br}^{-}$recovery was observed at 60 to $100 \mathrm{~cm}$, indicating upward flux of $\mathrm{Br}^{-}$from deeper layers. Although the mechanism of upward flux of $\mathrm{Br}^{-}$from deeper layers was not studied in this experiment, it may be presumed that high temperatures (average maximum $30^{\circ} \mathrm{C}$, minimum $20^{\circ} \mathrm{C}$ ) during dry spells cause water to start moving upward for rapid evaporation. Along with the water, a portion of $\mathrm{Br}^{-}$that was available in the lower layers may also start moving and be distributed in the upper profile. Possible upward lateral diffusion may also augment such fluxes.

In the context of $\mathrm{NO}_{3}^{-}$, the upward flux of $\mathrm{NO}_{3}^{-}$, which had been accumulated at a greater depth, has a positive significance in terms of $\mathrm{NO}_{3}^{-}$ availability to the crops plants, particularly those with deeper rooting systems.

For estimating leaching potential for $\mathrm{NO}_{3}^{-}$in this soil, the results clearly indicate that substantial losses of $\mathrm{NO}_{3}^{-}$could occur, particularly in the case of shallow rooted crops such as sorghum, pearlmillets, etc., because rooting of these crops is limited largely to $50 \mathrm{~cm}$ depth. It is evident from the massbalance estimates (Table 2 ) for the $\mathrm{Br}^{-}$profile to a depth of $100 \mathrm{~cm}$ that potential for leaching $\left(\mathrm{Br}^{-}\right.$or $\mathrm{NO}_{3}^{-}$) of this soil is high. For example, on 11 September, the $\mathrm{Br}^{-2}$ recovery from the 0 to $100-\mathrm{cm}$ depth was $58 \%$. Further sampling from 100 to 150 cm revealed the presence of $27 \%$ of $\mathrm{Br}^{-}$in this zone (Fig. 4) and that about $15 \%$ of the added $\mathrm{Br}^{-}$had moved beyond $150 \mathrm{~cm}$ depth. Thus, the earlier assumption (Krantz and Kampen 1978; Katyal 1994) that $\mathrm{NO}_{3}^{-}$leaching may not be a serious problem in deep Vertisols is not supported in this study. Bromide (or $\mathrm{NO}_{3}^{-}$) present in soil can leach down easily as it is not held firmly by the soil, and the transport may be rapid as a result of: (i) preferential flow of rain water down the cracks and large channels be- 

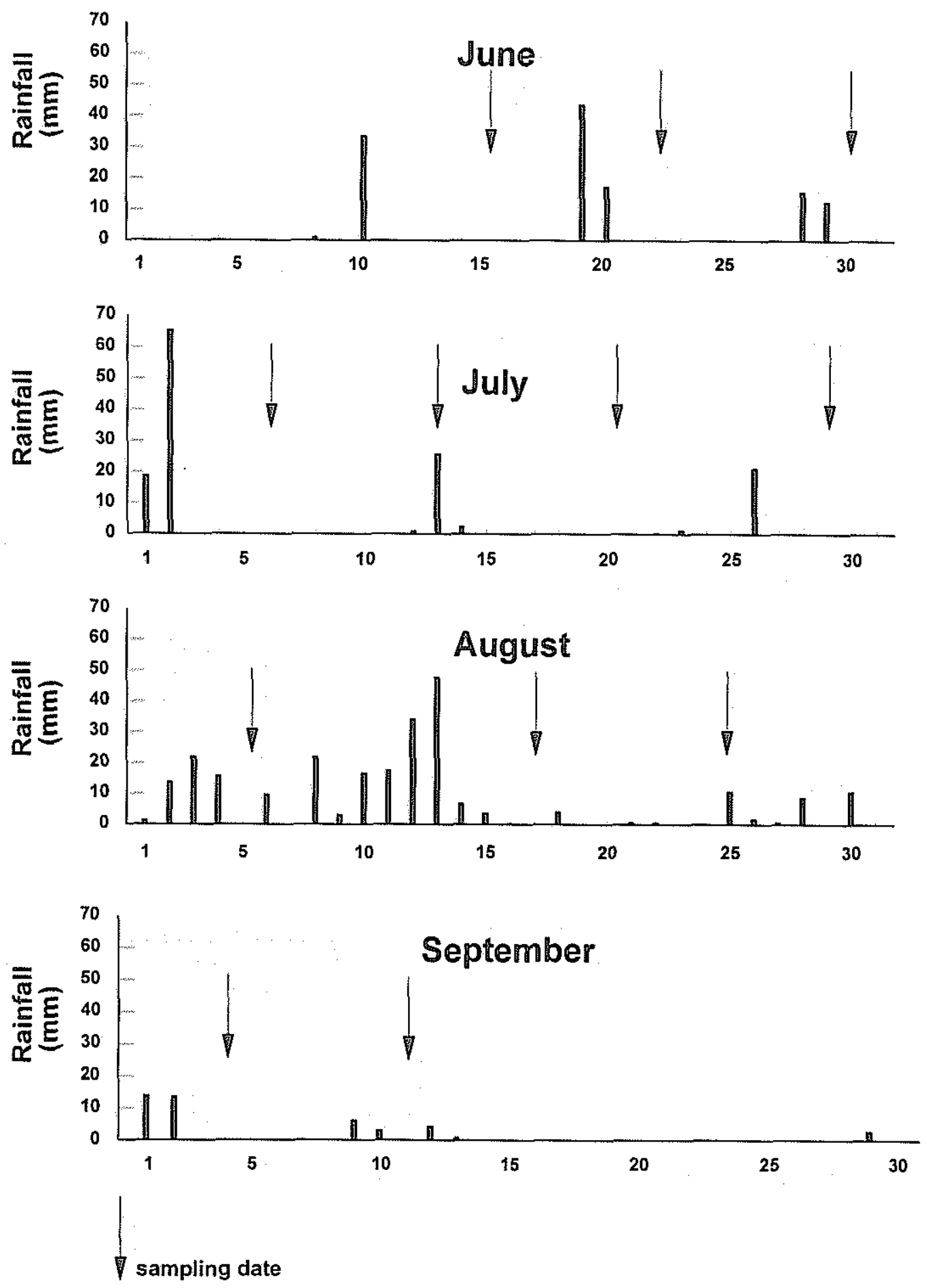

Fig. 3. Rainfall distribution (June-September) during 1992 at ICRISAT, Hyderabad, India. The inverted arrow indicates soil sampling dates for moisture and bromide estimation. 

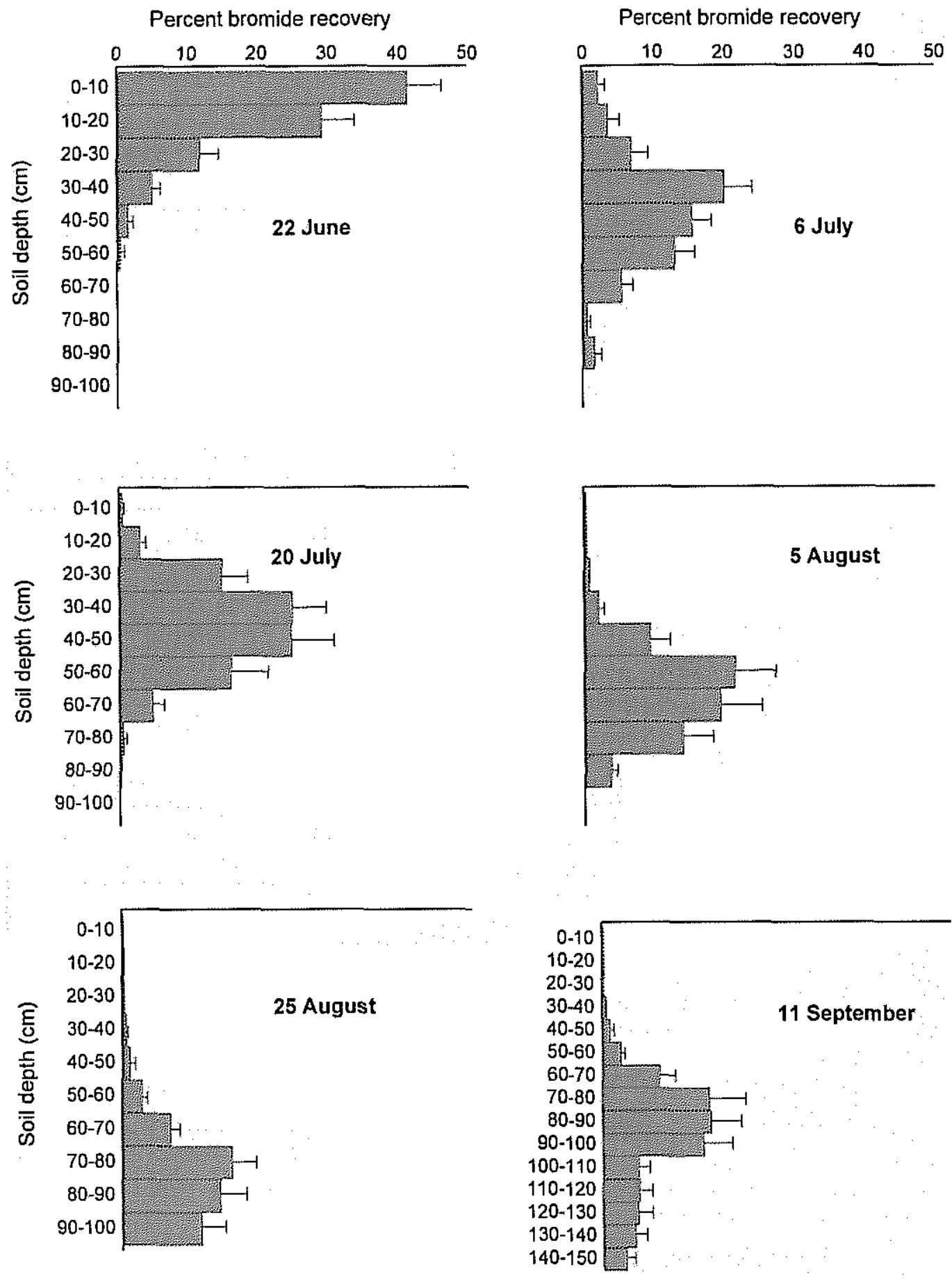

Fig. 4. Pattern of bromide distribution in a Vertisol profile on different dates after NaBr application on June 15, 1992. Data represent the mean of three replicates with standard error. 
TABLE 2

Precipitation, evaporation, and percenage of applied bromide recovery from the profile of a Vertisol, ICRISAT, India, on different dates after $\mathrm{NaBr}$ applicition

\begin{tabular}{|c|c|c|c|c|c|}
\hline $\begin{array}{l}\text { Sumpling } \\
\text { dates } \\
(1992) \\
\end{array}$ & $\begin{array}{l}\text { Total } \\
\text { precipitation } \\
\text { after preceding } \\
\text { sampling (1nm) }\end{array}$ & $\begin{array}{l}\text { Total evaporation } \\
\text { after preceding } \\
\text { sampling (mm) }\end{array}$ & $\begin{array}{c}\text { Cumulative } \\
\text { precipitation } \\
\text { (mm) }\end{array}$ & $\begin{array}{l}\text { Cumulative } \\
\text { evaporation } \\
\text { (mim) }\end{array}$ & $\begin{array}{c}\text { Percent applied } \mathrm{Br} \\
\text { recovered from } \\
\text { the profile } \\
(0-100 \mathrm{~cm})\end{array}$ \\
\hline 15 June & & & & & 101.4 \\
\hline 22 June & 61.4 & 61.7 & 61.4 & 61.7 & 90.1 \\
\hline 30 June & 31.8 & 47.6 & 93.2 & 109.3 & 91.1 \\
\hline of July & 84.6 & 33.8 & 177.8 & 143.1 & 70.1 \\
\hline 13 Jt:ly & 27.2 & 48.4 & 205.0 & 191.5 & 94.2 \\
\hline 20 July & 3,8 & 43.7 & 208.8 & 235.2 & 90.0 \\
\hline 28 July & 23.4 & 45.6 & 232.2 & 280.8 & 89.6 \\
\hline $05 \mathrm{Aug}$ & 53.0 & 40.3 & 285.2 & 321.1 & 72.0 \\
\hline 17 Aug & 164.8 & 45.2 & 450.0 & 366.3 & 36.0 \\
\hline 25 Aug & 17.4 & $3+.3$ & 467.4 & 400.6 & $5+.3$ \\
\hline 04 Sept & 49.5 & 35.7 & 516.9 & 436.3 & 45.2 \\
\hline $11 \mathrm{Sept}$ & 8.0 & 25.7 & 524.9 & 462.0 & 58.7 \\
\hline
\end{tabular}

Note: Bromide as $\mathrm{NaBr}$ was applied on June 15,1992 at $200 \mathrm{~kg} \mathrm{ha}^{-1}$.

tween aggregates through a soil profile (Wild and Babiker 1972; White 1988), and (ii) lateral diffusion through peds and slow downward movement through small channels, which may be further enhanced by anionic exclusions (Cameron and Wild 1982) causing transport at high velocity within the preferred chamnels. Bronide leaching may be further accentuated if applications of $\mathrm{Br}^{-}$are followed by heavy rainfall as it was during early July and first half of August in this experiment. In most soils, and especially in structured clay soils, $\mathrm{Br}^{-}$accumulated in the large pore system can be leached rapidly during large rains or irrigation. Bromide within aggregates is relatively protected during individual events, but between events it diffuses to the aggregate exteriors when it can be leached (Cameron and Wild 1982). In this study, lateral movement of $\mathrm{Br}^{-}$ out of the microplot may not be high as most of the $\mathrm{Br}^{-}(85 \%)$ was recovered from $150 \mathrm{~cm}$ depth, and only $15 \%$ was not accounted for, which may be lost through lateral movement or may be retained at below $150 \mathrm{~cm}$ depth. Moreover, application of $\mathrm{Br}^{-}$ between the microplot and the border of aluminiumsheet (Fig. 2) at the same rate was made purposely to minimize the effect of lateral movement even in large rainfall events.

The climatic data (Table 2) on total rainfall (525 $\mathrm{mm})$ and total evaporation $(462 \mathrm{~mm})$ during the experimental period do not indicate that the climatic potential for leaching of $\mathrm{NO}_{3}^{-}$is high. However, when the total rainfall and total evaporation are calculated on a weekly basis, it can be seen that the first half of August was a crucial period (see also Fig. 1), during which the soil $\mathrm{Br}^{-}$moved down heavily below the crop root zone. This study also suggests that measurement of climatic potential on a monthly basis as made by Smith and Cassel (1990) may not be appropriate for predicting $\mathrm{NO}_{3}^{-}$leaching from the soils of this region. Such calculations should be made at least on weekly basis (Patra and Singh 1996). As mentioned earlier, rain often comes in large stoms in the SAT of India (Huda et al. 1988); for example, the ICRISAT center received $85 \mathrm{~mm}$ rainfall in just 2 days (July $1-2,1992$ ). Under such conditions, the crop cannot be exw pected to take up all the $\mathrm{NO}_{3}^{+}$that is made aviliable during the wet season, and the result will be $\mathrm{N}$ deficiency at critical stages of crop growth.

Although this study has demonstrated the potential of this Vertisol for leaching of $\mathrm{NO}_{3}^{-}$, other species such as $\mathrm{NH}_{+}^{+}$and urea will undoubtedly move differently through the soil, and this needs to be evaluated. Furthermore, because there was no competition of roots for available $\mathrm{Br}^{-}$, all the readily available $\mathrm{Br}^{-}$was available for leaching with excess rainfall. In field conditions with growing crops, the extent of leaching of applied $\mathrm{NO}_{3}^{-}$would be reduced substantially because of plant uptake and $\mathrm{NO}_{3}^{-}$transformation processes such as denitrification and immobilization. Hong et al. (1992) have reported N losses as high as $61 \%$ of the applied $\mathrm{KNO}_{3}$ in a less wet year from a field experiment on a shallow Vertic Ustochrept (mean depth $45 \mathrm{~cm}$ ), with sorghum crops, having a rainfall of $485 \mathrm{~mm}$ in the period June-September 1984. Although Hong et al. (1992) did not measure $\mathrm{N}$ losses dim rectly, they explained that such losses were pre- 
sumably the result of leaching because of the shallow depth of the soil and intense rainfall following fertilizer application.

\section{CONCLUSIONS}

Results of the $\mathrm{Br}^{-}$movement patterns in this study infer that $\mathrm{NO}_{3}^{-}-\mathrm{N}$ (from soil or fertilizer application) not taken up by the crop may become vulnerable to leaching. This could be a serious constraint in such a soil if the crop-growing season is marked with periods of excessive rainfall (c.g., first halfof August). To overcome this problem, adequate attention must be given to fertilizer recommendations. This may be accomplished through sutitable agronomic practices such as the split application of fertilizer $\mathrm{N}$ during the critical stages of the crop, and increasing the rate of $\mathrm{N}$ application by suitable methods, such as foliar, immediately after the cessation of excessively rainy days may help in the quick recovery of the crops from $N$ deficiency and produce better yields.

\section{ACKNOWLEDGMENTS}

The first author (AKP) thanks the authorities of the Indian Council of Agricultural Research, New Delhi, for nominating him for postdoctoral research at ICRISAT. AKP is also indebted to the Director, Indian Grassland and Fodder Research Institute, Jhansi, India, for his kind help and encouragement during this program. Thanks are also due to S.C. Jarvis, IGER, North Wyke, Devon, UK, and two anonymous referees whose constructive comments/suggestions have been helpful in modifying this paper.

\section{REFERENCES}

Abdalla, N. A., and B. Lear. 1975. Determination of inorganic bronide in soils and plant tissues with bromide selective ion electrode. Commun. Soil Sci. Pl. Analysis. $6: 489-494$

Bicki, T. J, and G. Lei 1991. Tillage and sminlated ranfill intensity effect on bromide movement in an Argitudoll Soil Sci. Soc. Am. J. 55:794-799.

Blake, G. R. 1965: Bulk density: In Methods of soil analysis, part 1, C.A. Black etal. (eds.), \$SSA, Madison, WI, pp. $374-390$.

Bowman, R.S. 1984. Evaluation of sone new tracers for soil water studies. Sól Sci. Soc. Am. J. 48:987-993.

Bremner, J. M. 1965 . Inorganic forms of nitrogen. In Methods of soil analysis, part 2. C.A. Bhack et al. (eds.) SSSA, Madison, WI, pp. 1179)-1232.

Bremner, J. M., and C. S. Mulviney. 1982, Total Nitrogen. In Methods of soil analysis, part 2, 2nd Ed. A.L. Page et al. (eds.). SSSA, Madison, WI, pp. $595-624$
Cameron, K. C., and A. Wild. 1982. Comparative rates of leaching of chloride, nitrate, and tritiated water under field conditions. J. Soil Sci. 33:649-657.

Craswell, E. T., and A. E. Martin. 1974. Effect of moisture content on denitrification in a clay soil. Soil Biol. Biochem. 10:2+1-245.

El-Swaify, S. A., P. Pathak, T. J. Rego, and S, Singh. 1985. Soil managenent for optimized productivity under rainfed conditions in the semi-arid tropics. Adv. Soil Sci. 1:1-64.

Hargrove, R. S., and W. C. Bausch. 1973. The use of bromide tracer for comparison of fertilizer leaching rates. Agron. Abstr.

Hargrove, W. L. 1988. Evaluation of ammonic volatilization in the field.J. Prod. Agric 1:104-111.

Hong, C. W., J. C. Katyal, and P. L. G. Vlek, 1992. Losses and utilization of nitrogen by sorghum as affected by depth of a swelling clay soil. J. Agron. Crop Sci. 168:263-271.

Huda, A. K. S., P. Patlak, T. J. Rego, and S. M. Virmani. 1988. Agroclimatic considerations for improved soil and water management and efficient fertilizers use in semi-arid India. Fert. News 33:51-57.

ICRISAT (International Crops Research Institute for the Semi-Arid Tropics). 1978. Ammal Report for 1977-78. Patancheru, Hyderabad, A. P., India.

Jackson, M. L. 1967. Soil chemical analysis. Prentice Hall of India Pvt. Ltd., New Delhi.

Katyal j. C. 1994 . Nutrient management in soil of arid and semi-irid regions. In Soil management for sustainable agriculture in dryland areas, Bull. 16. Indian Soc: Soil Sci., New Delhi, India, pp. 78-91.

Kissel; D. E., J. T. Ritchie, and E. Burnett. 1974 . Nitrate and chloride leaching in swelling clay soil. J. Environ. Qual, 3:401-404.

Krantz, B. A., and J. Kampen. 1978. Soil and water numagement in the semi-arid tropics. In Soil resource data for agricultural development. L.D. Swindale (ed.), Hawaii Agricultural Experiment Station, College of Tropical Agriculture, University of Hawaii, pp. 228-242.

Levy, B. S., and R. M. Cliambers. 1987. Bromide as a conservative tracer for soil-water studies. Hydrol, Processes 1:385-389.

Li, Y, C., A. K. Alva, D. V. Calvert, and D. J. Banks. 1995. Adsorption and transport of nitrate and bromide in a Spodosol. Soil Sci. 160:400-404.

Onken, A. B., C. W. Wendr, R. S. Hargrove, and O. C. Wilke. 1977. Relative movement of bromide and nitrate in soils under three irrigation system. Soil Sci, Soc. Am. J. 41:50-52.

Patra A. K., and T.J. Rego. 1994. Modified procedure forbronide estiniation with ion-selective electrode for predicting nitrate movement in soil. Curr Sci. $67: 545-546$

Patra A. K., J. R. Burford, and T. J. Rego. 1996. Volatilization losses of surfacemapplied urea nitrogen from the Vertisols in the Indian semi-arid tropics. Biol. Fertil. Soils. 22:3 $45-349$.

Patra, A. K, and J. B. Singl. 1996. Predicting critical 
periods of nitrate leaching from soils of a semi-arid region. Fert. News 41:51-53.

Silvertooth J. C.. J. E. Watson, J. E. Malcuit, and T. A. Deorge. 1992. Bromide and nitrate movement in an irrigated cotton production system. Soil Sci. Soc. Am. J. 56:548-555.

Smith, S. J., and D. K. Cassel. 1990. Estimating nitrate leaching in soil materials. In Managing nitrogen for ground water quality and farm profitability. R.F. Follet (ed.). SSSA, Madison, WI.

Smith S. J., and R. J. Davis. 1974. Relative movement of bromide and nitrate through soils. J. Environ. Qual. 3:152-155.

Virgo, K. J. 1981. Observation of cracking in Somali Vertisols. Soil Sci. 131:60-61.
Virmani, S. M., K. L. Sahrawat, and J. R. Burford. 1982. Physical and chemical properties of Vertisols and their management. In Vertisols and rice soils of the tropics. Symp. paper II. Trans. 12th Congress on Soil Science, New Delhi, India, pp. 80-93.

Walkley, A., and I. A. Black. 1934. Estimation of soil organic carbon by the chromic acid titation method. Soil Sci. 47:29-38.

White, R. E. 1988. Leaching. In Advances in nitrogen cycling in agril. ecosystems. J.R. Wilson (ed.). CAB Int., Oxon, UK., pp. 257-273.

Wild, A., and 1. A. Babiker. 1972. The asymmetric leaching pattern of nitrate and chloride in a loamy sand under field conditions. J. Soil Sci. 27:460-466. 